\title{
URGENSI PEMBENTUKAN REGULASI GRASI, AMNESTI, ABOLISI DAN REHABILITASI
}

\section{(Urgency of Formation Regulation Gration, Amnesty, Abolition, and Rehabilitation)}

\author{
Sujatmiko*, Willy Wibowo* \\ *Badan Penelitian dan Pengembangan Hukum dan HAM \\ Kementerian Hukum dan Hak Asasi Manusia RI, Jakarta \\ Corresponding email: soejat@yahoo.com
}

Tulisan Diterima: 21-01-2021; Direvisi: 16-02-2021; Disetujui Diterbitkan: 17-02-2021
DOI: $\quad \underline{\text { http://dx.doi.org/10.30641/deiure.2021.V21.091-108 }}$

\begin{abstract}
Legal polemics regarding the granting of clemency, amnesty, abolition and, rehabilitation as in the case of Baiq Nuril, Budiman Sudjatmiko, the Governor of Riau, Corby and, Grobmann arise because the regulations governing the granting of the prerogative of the President in the judicial sector are not appropriate with legal problems in Indonesia. For this reason, the urgency for the formulation of the Law on Clemency, Amnesty, Abolition and, Rehabilitation. This article aims to analyse the urgency of the Law's formulation on Clemency, Amnesty, Abolition and, Rehabilitation. The research method used is qualitative with an empirical normative approach. Field data collection was carried out through focus group discussions with resource persons. This study concludes that the Draft Law on Clemency, Amnesty, Abolition and, Rehabilitation is urgent to form a new law for adjustment to the constitution and legal developments that prioritize the principles of human rights, as the implementation of the prerogative of the President as regulated in Article 14 Paragraphs 1 and 2. It is based on considerations of constitutional changes and the legal needs of the community, aims to facilitate the President to using his prerogatives and to ensure that the principles of accountability, the principles of public transparency, the implementation of monitoring and evaluation, and checks and balances as of the manifestation of implementing good governance. Suggestions from this research are that the Ministry of Law and Human Rights through main units such as Balitbangkumham, BPHN, DItjen AHU and, Directorate General PP prepare supporting documents for the Draft Law on Clemency, Amnesty, Abolition and, Rehabilitation to enter into the 2022 prolegnas.
\end{abstract}

Keywords: regulation; clemency; amnesty; abolition; rehabilitation

\begin{abstract}
ABSTRAK
Polemik hukum terkait pemberian Grasi, Amnesti, Abolisi dan Rehabilitasi seperti pada kasus Baiq Nuril, Budiman Sudjatmiko, Gubernur Riau, Corby dan Grobmann timbul karena regulasi yang mengatur pemberian hak prerogatif Presiden di bidang yudisial tersebut sudah tidak sesuai dengan permasalahan hukum di Indonesia. Untuk itu bagaimanakah urgensi dibentuknya Undang-undang Grasi, Amnesti, Abolisi dan Rehabilitasi, artikel ini bertujuan untuk menyajikan analisis urgensi dibentuknya Undang-undang Grasi, Amnesti, Abolisi dan Rehabilitasi. Metode penelitian yang digunakan adalah kualitatif dengan pendekatan normatif empiris. Pengumpulan data lapangan dilakukan dengan focus group discussion dengan narasumber. Penelitian ini menyimpulkan bahwa Rancangan Undang-undang Grasi, Amnesti, Abolisi dan Rehabilitasi bersifat urgen untuk segera di bentuk Undang-undang baru guna penyesuaian terhadap konstitusi dan perkembangan hukum yang mengedepankan prinsip-prinsip Hak Asasi Manusia, sebagai implementasi hak prerogatif Presiden sebagaimana diatur di dalam Pasal 14 Ayat 1 dan 2. Hal ini didasarkan kepada pertimbangan perubahan ketatanegaraan dan kebutuhan hukum masyarakat, bertujuan untuk memudahkan Presiden dalam menggunakan hak prerogatifnya serta untuk memastikan bahwa asas akuntabilitas, asas transparansi publik, pelaksanaan monitoring dan evaluasi, serta check and balances sebagai perwujudan pelaksanaan good governance. Saran dari penelitian ini agar Kementerian Hukum dan HAM melalui unit utama seperti Balitbangkumham, BPHN, DItjen AHU dan Ditjen PP mempersiapkan dokumen pendukung Rancangan Undang-undang Grasi, Amnesti, Abolisi dan Rehabilitasi agar masuk ke dalam prolegnas Tahun 2022.
\end{abstract}

Kata kunci: peraturan; grasi; amnesti; abolisi; rehabilitasi 


\section{PENDAHULUAN}

Pada akhir Juli 2019, Baiq Nuril yang mendapatkan amnesti dari Presiden Joko Widodo melalui Keputusan Presiden Nomor 24 Tahun 2019, hal ini merupakan kebutuhan hukum masyarakat yang perlu dipertimbangkan dalam hal praktek pemberian amnesti dinegara Indonesia. Karena Baiq Nuril bukan didakwa dengan tindak pidana politik namun didakwa dengan tindak pidana informasi dan transaksi elektronik (ITE) kasus Baiq Nuril bisa menjadi momentum tepat untuk Indonesia dalam membuat Undang-undang (UU) yang baru terkait pemberian amnesti karena aturan hukum sekarang masih rancu dan ambigu. ${ }^{1}$

Kasus ini bermula saat Baiq Nuril dituduh menyebarkan rekaman percakapan telepon dengan atasannya, Kepala SMAN 7 Mataram, H Muslim. Muslim ditengarai melakukan pelecehan seksual secara verbal dalam percakapan itu. Tak terima tersebar rekaman percakapan itu, Muslim mempolisikan Baiq hingga berujung ke pengadilan. Di pengadilan tingkat pertama Baiq dinyatakan bebas karena tidak terbukti atas dakwaan UU ITE. Atas vonis bebas ini, Jaksa mengajukan kasasi. Dalam putusan kasasi MA, menghukum Baiq selama 6 bulan penjara dan denda Rp500 juta. Baiq terbukti menyebarkan konten yang mengandung kesusilaan seperti diatur Pasal 27 ayat (1) UU No. 11 Tahun 2008 jo UU No. 19 Tahun 2016 tentang ITE. Majelis Mahkamah Agung (MA) pun menolak permohonan PK Baiq Nuril.

Kasus Baiq Nuril kemudian menjadi perdebatan bagi kalangan ahli hukum, solusi hukum yang tepat untuk menjamin rasa keadilan dan sebagai wujud perlindungan negara kepada warga negara apakah dengan pemberian grasi atau dengan pemberian amnesti pakar hukum tata negara, Bivitri Susanti, mengatakan pemberian grasi tidak sesuai dengan konteks kasus yang menjerat. ${ }^{2}$ Grasi mensyaratkan minimal hukuman terdakwa dua tahun, mendapat persetujuan dari DPR, dan diajukan oleh terpidana. Sementara Nuril hanya diancam penjara enam bulan. Kemudian pada akhirnya Presiden Joko Widodo, dalam

1 Dio Ashar Wicaksana dan Josua Satria Collins, "Analisis Dibalik Kontroversi Pemberian Amnesti Jokowi Kepada Baiq Nuril: Indonesia Butuh UU Amnesti Yang Baru," Dio Ashar Wicaksana Dan Josua Satria Collins, last modified 2020, accessed July 31, 2020, tehconversation.com.

2 Anonim, "Kasus Baiq Nuril: Solusi Hukum Grasi Atau Amnesti," Bbc Indonesia, last modified 2018, accessed January 13, 2021, rangka memberikan keadilan kepada Baiq Nuril memutuskan untuk memberikan amnesti.

Amnesti yang telah diberikan Presiden Joko Widodo kepada Baiq Nuril menjadi peristiwa tonggak sejarah dalam sistem hukum di Indonesia. Karena baru kali ini amnesti diberikan atas pertimbangan dasar kemanusian. Biasanya amnesti diberikan dalam kasus politik, contohnya seperti amnesti dan abolisi yang diberikan kepada para mantan pengikut Gerakan Aceh Merdeka

Sebagai Negara yang menganut sistem Pemerintahan Presidensial, Indonesia dipimpin oleh seorang Presiden yang mempunyai otoritas besar dan kuat. Selain sebagai kepala negara dan kepala Pemerintahan, Presiden juga memiliki hak istimewa atau hak ekslusif yang melekat padanya atau yang biasa disebut hak prerogratif. ${ }^{3}$ Hak prerogratif secara teoritis diartikan sebagai hak istimewa yang dimiliki oleh lembaga-lembaga tertentu yang bersifat mandiri dan mutlak. ${ }^{4}$ Hak prerogratif Presiden membawahi banyak bidang salah satunya adalah bidang yudisial. Hak prerogratif Presiden dalam bidang yudisial adalah membuat keputusan terkait dengan pemberian grasi, amnesti, abolisi dan rehabilitasi (GAAR) bagi mereka yang sedang berhadapan dengan proses hukum sebagaimana diamanatkan Pasal 14 ayat (1) dan Pasal 14 ayat (2) UUD 1945. Pasal 14 ayat (1) Presiden memberi grasi dan rehabilitasi dengan memperhatikan pertimbangan MA Pasal 14 ayat (2) Presiden memberikan amnesti dan abolisi dengan memperhatikan pertimbangan Dewan Perwakilan Rakyat (DPR).

Kemudian amnesti dan abolisi diatur dalam UU Darurat Nomor 11 Tahun 1954 Tentang Amnesti dan Abolisi. Didalam konsideren menimbang bahwa UU Darurat ini dibuat dalam rangka melaksanakan ketentuan dalam pasal 107 UU Dasar Sementara Republik Indonesia (UUDS 1950) dan untuk menyesuaikan penetapan Presiden Republik Indonesia No. 14 tahun 1949 tentang pemberian amnesti. Didalam UU Darurat tersebut tidak mengatur tentang definisi amnesti dan abolisi, hanya didalam pasal 1 UUDS 1950 tersebut diatur Presiden, atas kepentingan Negara, dapat

https://www.bbc.com/indonesia/indonesia46278770.

3 Yuvina Aristanti, "Sakit Berkepanjangan Sebagai Hak Untuk Mengajukan Grasi Berdasarkan Alasan Kemanusiaan Dan Keadilan” (Universitas Airlangga, 2019).

4 KBBI, "Kamus Besar Bahasa Indonesia Online," last modified 2020, accessed July 30, 2020, http://bahasa.kemendiknas.go.id/kbbi/index.php. 
memberi amnesti dan abolisi kepada orang-orang yang telah melakukan sesuatu tindakan pidana.

Presiden memberi amnesti dan abolisi ini setelah mendapat nasihat tertulis dari MA yang menyampaikan nasihat itu atas permintaan Menteri Kehakiman. Lebih lanjut didalam Pasal 2 amnesti dan abolisi diberikan kepada semua orang yang sebelum tanggal 27 Desember 1949 telah melakukan sesuatu tindak pidana yang nyata akibat dari persengketaan politik antara Republik Indonesia (Yogyakarta) dan Kerajaan Belanda. Menurut Pasal 4 UU Darurat tersebut dengan pemberian amnesti semua akibat hukum pidana terhadap orang-orang termaksud dalam pasal 1 dan 2 dihapuskan. Dengan pemberian abolisi maka penuntutan terhadap orang-orang yang termaksud dalam pasal 1 dan 2 ditiadakan.

Jika melihat ketentuan Pasal 2 UU Darurat tentang Amnesti dan Abolisi, amnesti dan abolisi diberikan kepada mereka yang melakukan tindak pidana politik berdasarkan penelusuran dalam sistem informasi Perundang-undangan Sekretariat Kabinet RI, Pemerintah Indonesia sudah memberikan 32 amnesti mulai dari bangsa ini merdeka hingga sekarang. Dalam daftar, para penerima amnesti adalah memang orang-orang yang terlibat dalam gerakan politik. Landasan pemberian amnesti mereka adalah perlindungan Hak Asasi Manusia (HAM). ${ }^{5}$

Jika merujuk kepada konsideren menimbang UU No.11 Tahun 1945, UU ini masih mendasarkan kepada UUDS 1950. Padahal untuk kondisi sekarang UUDS 1950 sudah tidak lagi menjadi Konstitusi NKRI tetapi yang menjadi konstitusi adalah UUD 1945. UU darurat tersebut menentukan pemberian amnesti menggunakan mekanisme berbeda dengan UUD 1945.

Belum lagi berbicara mengenai grasi, dalam perkembangannya, terdapat Keputusan Mahkamah Konstitusi (MK) melalui Putusan Nomor 107/PUU-XIII/2015. Melalui putusan tersebut yang terdapat dalam amar putusannya MK mengabulkan permohononan pemohon seluruhnya, menyatakan Pasal 7 ayat (2) UU No. 5 Tahun 2010 tentang Perubahan Atas UU No. 22 Tahun 2002 tentang Grasi bertentangan dengan UUD 1945 dan tidak mempunyai kekuatan hukum mengikat. ${ }^{6}$ Putusan tersebut memiliki dampak pada

5 Collins, “Analisis Dibalik Kontroversi Pemberian Amnesti Jokowi Kepada Baiq Nuril: Indonesia ButuhUUAmnestiYang Baru."

6 Mohammad Rezza Naufa Dkk, "Analisis Yuridis Putusan Mahkamah Konstitusi Nomor 107/PuuXiii/2015 Tentang Pengujian UndangUndang Nomor 5 Tahun 2010 Tentang Perubahan perubahan jangka waktu dalam pengajuan permohonan grasi yang sebelumnya paling lama satu tahun setelah putusan berkekuatan hukum tetap menjadi tidak dibatasi oleh waktu.

Sedangkan rehabilitasi pengaturannya terdapat pada Pasal 14 ayat (1) UUD 1945, dan belum diatur didalam UU. Amnesti, abolisi dan rehabilitasi sampai saat ini belum mempunyai regulasi yang jelas sebagai dasar hukum pelaksanaannya. Kedepannya regulasi mengenai GAAR harus menyesuaikan dengan perkembangan hukum pidana di Indonesia. Penyesuaian tersebut membutuhkan sebuah regulasi yang mengatur secara detil mengenai pengertian, mekanisme, prosedur, kriteria dan lembaga yang terlibat dalam pelaksanaannya. diharapkan dengan adanya regulasi yang jelas tentang GAAR, maka pelaksanaan hak prerogatif Presiden dapat dilaksanakan secara optimal dalam pemberian keadilan kepada masyarakat. Sudah ada arahan Menteri Hukum dan HAM tanggal 16 Juli 2019 pada rapat kerja dengan DPR yang akan segera menyusun perubahan UU tentang GAAR sebagai pelaksanaan dari Pasal 14 ayat (1) dan (2) UUD 1945 agar payung hukum pelaksanaan GAAR menjadi lebih jelas dan terang sehingga dalam UU tersebut nantinya.

Berdasarkan latar belakang di atas, berikut rumusan masalah yang relevan untuk dikaji lebih lanjut dalam penelitian ini yaitu, apa urgensi pembentukan regulasi dibidang GAAR oleh Pemerintah?

\section{METODE PENELITIAN}

Penelitian ini menggunakan pendekatan penelitian hukum dalam konteks normatif empiris, memiliki definisi sebagai penelitian yang berfokus kepada pemberlakuan ketentuan hukum normatif (kodifikasi, UU atau kontrak) secara in action pada setiap peristiwa hukum tertentu yang terjadi dalam masyarakat. ${ }^{7}$ Penelitian normatif merupakan penelitian yang dilakukan untuk menelaah hal-hal teoritis yang menyangkut asas-asas hukum, konsepsi hukum, pandangan dan doktrin-doktrin hukum, serta peraturan dan sistem hukum dengan menggunakan data sekunder berupa asas, kaidah, norma dan aturan hukum yang terdapat dalam

Atas Undang-Undang Nomor 22 Tahun 2002 Tentang Grasi Terhadap Undang-Undang Dasar Negara Republik Indonesia Tahun 1945," Diponogoro Law, Fakultas Hukum Universitas Diponogoro Volume 6 N (2017): 3.

7 Abdulkadir Muhammad, Hukum Dan Penelitian Hukum (Bandung: Citra Aditya Bakti, 2004). 
peraturan perundang-undangan dan peraturan regulasi lainnya. ${ }^{8}$ Penelitian hukum empiris dilakukan dengan penelitian lapangan yang bertujuan untuk melihat secara langsung penerapan peraturan perundang-undangan atau aturan hukum yang berkaitan dengan penegakan hukum.

Penelitian ini adalah penelitian yang bersifat deskriptif analitis, memiliki tujuan untuk menggambarkan kondisi sebenarnya yang terjadi di lapangan. ${ }^{9}$ Penelitian deskriptif memiliki definisi sebagai penelitian yang bertujuan untuk membuat deskripsi atau lukisan secara sistimatis, faktual dan akurat mengenai fakta-fakta, sifat-sifat serta hubungan antara fenomena yang diselidiki.

Teknik pengumpulan data yang dipergunakan dalam penelitian ini adalah sebagai berikut: Data Primer. Pengumpulan data primer dalam penelitian ini sedianya dilakukan melalui metode Focus Group Disscusion secara langsung kepada narasumber penelitian. Adapun Narsumber penelitian terdiri dari dari: 1). Dosen Hukum Tata Negara dan Pidana 2). Organisasi profesi hukum 3) NGO yang konsen terhadap permasalahan hukum dan HAM 4) aparat penegak hukum (polisi, jaksa dan hakim) 5) Kepala Divisi Pelayanan Hukum dan HAM dan Kepala Divisi Pemasyarakatan Kantor Wilayah Kementerian Hukum dan HAM. Data Sekunder. Data sekunder diperoleh melalui studi kepustakaan (library study), dengan bahan-bahan berupa: a) bahan hukum primer, terdiri dari peraturan perundang-undangan yang terkait dengan GAAR dan b) bahan hukum sekunder berupa buku, jurnal, hasil penelitian terkait, serta makalah yang relevan dengan permasalahan penelitian; dan c) bahan hukum tersier, berupa bahan hukum yang memberikan petunjuk maupun penjelasan terhadap bahan hukum primer dan sekunder, seperti kamus dan ensiklopedia.

Analisis data dalam penelitian ini menggunakan analisis kualitatif, analisis kualitatif yang dilakukan bertitik tolak dari analisis empiris, yang dalam pendalamannya dilengkapi dengan analisis normatif. Dalam menganalisis data mempergunakan model interaktif yang meliputi kegiatan reduksi data, penyajian data dan penarikan kesimpulan. Penelitian ini dilakukan di 3 lokasi penelitian yaitu DKI Jakarta, Jawa Timur dan Sumatera Barat.

8 Soerjono Soekanto, Penelitian Hukum Normatif (Jakarta: PT Raja Grafindo Peresada, 2006).

9 Hadari Nawawi, Penelitian Terapan (Yogyakarta: Gadjah Mada University Press, 2005).

10 Mahfud MD, Membangun Politik Hukum Menegakkan Konstitusi (Jakarta: Rajawali Pers, 2010).

\section{PEMBAHASAN}

Sistem Pemerintahan yang dianut oleh Negara Kesatuan Republik Indonesia adalah Presidensial. Hal ini dapat kita lihat pada Pasal 6A UUD Tahun 1945, Sistem hukum nasional merupakan kesatuan hukum dan perundangundangan yang terdiri dari banyak komponen yang saling bergantung, yang dibangun untuk mencapai tujuan negara dengan berpijak pada dasar dan cita hukum negara yang terkandung di dalam Pembukaan dan Pasal-pasal UUD 1945. ${ }^{10}$ Dimana pokok ketentuan yang terkandung didalamnya menegaskan bahwa mekanisme pengisian jabatan Presiden dan wakil Presiden ialah dipilih secara langsung oleh rakyat. Salah satu poros kekuasaan dalam konsep trias politica adalah kekuasaan eksekutif yang pada dasarnya merupakan cabang kekuasaan yang memegang kewenangan administrasi pemerintahan negara tertinggi. ${ }^{11}$

Dalam bahasa Inggris, sistem pemerintahan

presidensial disebut the NonParliamentary Executive atau a system of Presidential Government atau a fixed executive. ${ }^{12}$ Berdasarkan pendapat dari Richard Albert, sistem pemerintahan presidensial memiliki ciri, "the executive and legislative branches are selected in separate elections by citizens, the government is not subject to parliamentary votes of no confidence, and the executive power is vested in one individual". Jadi, sistem pemerintahan presidensial dengan ciri utama: hanya ada satu pemegang kekuasaan eksekutif (single executive).

Sistem presidensial merupakan sistem pemerintahan yang terpusat pada jabatan presiden sebagai kepala pemerintahan (head of government) sekaligus sebagai kepala negara (head of state). Presiden sebagai kepala Negara sekaligus menjadi Kepala Eksekutif. Itulah sebabnya rentang kekuasaan presiden tidak hanya menyentuh wilayah eksekutif, tetapi juga sedikit banyak merambah pada proses legislasi serta kewenangan di bidang yudikatif. Presiden bukan dipilih oleh parlemen tetapi Presiden beserta parlemen samasama dipilih secara langsung oleh rakyat melalui suatu pemilihan umum. Karena itu Presiden tidak bertanggung jawab kepada parlemen sehingga Presiden dan kabinetnya tidak dapat dijatuhkan

11 Jimly Asshiddiqie, Pengantar Ilmu Hukum Tata Negara (Depok: Rajawali Pers, 2019).

12 Rosjidi Ranggawidjaja, Hubungan Tata Kerja Antara Majelis Permusyawaratan Rakyat, Dewan Perwakilan Rakyat Dan Presiden (Bandung: Gaya Media Pratama, 1990). 
oleh parlemen. Sebaliknya Presiden pun tidak dapat membubarkan parlemen. Bentuk pemerintahan seperti ini disebut sebagai sistem pemerintahan presidensiil (fixed executive). Menurut Juan J. Linz, ada dua hal menonjol dari presidential government. The first is the president's strong claim to republic, even plebiscitarian, legitimacy, the second is his fixed term in office.

Ciri-ciri atau prinsip yang terdapat dalam sistem presidensial menurut Mahfud MD sebagai berikut: ${ }^{13}$

a) Kepala negara menjadi kepala pemerintahan (eksekutif);

b) Pemerintah tidak bertanggung jawab kepada parlemen (DPR);

c) Menteri-menteri diangkat dan bertanggung jawab kepada Presiden;

d) Eksekutif dan legislatif sama-sama kuat.

Dengan adanya pemisahan yang tegas antara pemegang kekuasaan eksekutif dan pemegang kekuasaan legislatif, dalam sistem presidensial pembentukan pemerintah tidak tergantung pada proses politik di Lembaga legislatif.

Sebagai negara yang menganut sistem pemerintahan Presidensial, Indonesia dipimpin oleh seorang Presiden yang mempunyai otoritas besar dan kuat. Selain sebagai kepala negara dan kepala pemerintahan, Presiden juga memiliki hak istimewa atau hak ekslusif yang melekat padanya atau yang biasa disebut hak prerogratif dibidang yudisial seperti pemberian GAAR.

Hak prerogatif presiden masih termuat dalam UUD 1945 setelah amandemen. Hak prerogatif Presiden tersebut terdapat dalam Pasal 22 Ayat 1 UUD 1945 yang memuat ketentuan tentang peraturan presiden pengganti UU yang merupakan wewenang Presiden untuk mengeluarkannya. Pasal 22 Ayat 1 UUD 1945 ini merupakan satu-satunya pasal dalam UUD 1945 setelah amandemen yang masih dapat diidentifikasikan sebagai hak prerogatif Presiden. ${ }^{14}$

Dalam prakteknya kekuasaan Presiden Republik Indonesia sering disebut dengan istilah "hak prerogatif Presiden" dan diartikan sebagai kekuasaan mutlak Presiden yang tidak dapat diganggu gugat oleh pihak lain. Secara teoritis, hak prerogatif diterjemahkan sebagai hak istimewa yang dimiliki oleh lembaga-lembaga tertentu

13 Mahfud MD, Dasar Dan Struktur Ketatanegaraan Indonesia, Edisi Revi. (Jakarta: Rineka Cipta, 2001).

14 H. Fahmi Yoesmar AR. dan Mahesa Rannie, "Hak Prerogatif Presiden Di Indonesia Pasca Amandemen
(Presiden) yang bersifat mandiri dan mutlak, dalam arti tidak dapat digugat oleh lembaga negara yang lain.

\section{Grasi}

Kata grasi berasal dari bahasa latin Pardonare, yang di terjemahkan kedalam bahasa Inggris yaitu Pardone. Menurut Blacks Law Dictionary Sixth Edition, yang disusun oleh Henry Campbell Black. M.A Tahun 1990 dituliskan bahwa Pardon: an executive action that mitigates or sets aside punishment for a crime. An act of grace from governing power which mitigates the punishment the law demands for the offense and restores the right and privileges forfeited on account of the offense. Grasi diatur dalam UU No. 22 Tahun 2002 yang telah dirubah dalam UU No. 5 Tahun 2010. Menurut Pasal 1 UU No. 20 Tahun 2002, yang dimaksud grasi adalah pengampunan berupa perubahan, peringanan, pengurangan, atau penghapusan pelaksanaan pidana kepada terpidana yang diberikan oleh Presiden.

Selain upaya hukum luar biasa, untuk menghindari dilaksanakannya pidana mati, terpidana melalui kuasa hukumnya seringkali mengajukan grasi kepada Presiden untuk mengubah putusan pidana mati tersebut. Dalam Rancangan Kitab Undang-Undang Hukum Pidana (RKUHP), pidana mati disebutkan akan otomatis menjadi pidana seumur hidup apabila sepuluh tahun setelah keputusan penolakan grasi dikeluarkan oleh Presiden, dan jaksa belum melaksanakan eksekusi pidana mati tersebut.

Hal ini berarti jaksa harus melaksanakan pidana mati sebelum sepuluh tahun setelah adanya penolakan kasasi Perlunya diskusi norma Pasal 7 ayat (2) UU No.5 Tahun 2010 tentang Perubahan Atas UU No. 22 Tahun 2002 tentang Grasi. Dimana pasal tersebut berbunyi permohonan grasi sebagaimana dimaksud pada ayat (1) diajukan paling lama dalam jangka waktu 1 tahun sejak putusan memperoleh kekuatan hukum tetap. Permasalahan disini timbul selain membatasi, menghalangi, hak konstitusional Presiden sebagai kepala negara untuk memberikan grasi, hal tersebut juga menjadi masalah bila mengajukan lebih dari 1 tahun maka permohonan grasi tersebut menjadi daluarsa.

Jika dilihat dari persfektif hukum pidana, kewenangan Presiden berkaitan dengan Pasal 14

UUD 1945," in Seminar Nasional Hasil-Hasil Peneliti Ilmu Hukum Tahun 2015 (Palembang: Fakultas Hukum Universitas Sriwijaya, 2015), 25. 
UUD 1945 tentang Grasi dan UU No. 22 Tahun 2002 sebagaimana dirubah dengan UU No. 5 Tahun 2010 tentang Grasi sesungguhnya berkaitan erat dengan dua hal penting dalam hukum pidana, yakni perihal hapusnya kewajiban menjalankan pidana dan tujuan pemidanaan. Dari persfektif ini dapat disimpulkan bahwa berkaitan dengan grasi maka sesunggunya Presiden menyerap sebagian kecil kewenangan hakim dalam menetapkan jenis pidana yang dijatuhkan dan lamanya seseorang menjalani pemidanaan.

Dalam Pasal 2 ayat (1) UU No. 5 Tahun 2010 diatur bahwa terhadap putusan pengadilan yang telah memperoleh kekuatan hukum tetap, terpidana dapat mengajukan permohonan grasi kepada Presiden. Kata "dapat" dalam ketentuan ini dimaksudkan untuk memberikan kebebasan kepada terpidana untuk menggunakan atau tidak menggunakan hak untuk mengajukan permohonan grasi sesuai dengan UU No. 5 Tahun 2010.

Hak mengajukan grasi diberitahukan kepada terpidana oleh hakim atau hakim ketua sidang yang memutus perkara pada tingkat pertama. Jika pada waktu putusan pengadilan dijatuhkan terpidana tidak hadir, hak terpidana diberitahukan secara tertulis oleh panitera dari pengadilan yang memutus perkara pada tingkat pertama, banding atau kasasi. Putusan pemidanaan yang dapat dimohonkan grasi adalah pidana mati, pidana penjara seumur hidup, atau pidana penjara paling rendah 2 tahun. Perlu di ingat bahwa permohonan grasi hanya dapat diajukan 1 kali, agar memberikan kepastian hukum dalam pelaksanaan pengajuan permohonan grasi dan menghindari pengaturan diskriminatif.

Pihak yang dapat mengajukan permohonan grasi secara tertulis adalah:

a) Terpidana atau kuasa hukumnya;

b) Keluarga terpidana dengan persetujuan terpidana, keluarga yang dimaksud adalah isteri atau suami, anak kandung, orang tua kandung, atau saudara sekandung terpidana;

c) Keluarga terpidana tanpa persetujuan terpidana, apabila terpidana dijatuhi pidana mati.

Presiden berhak mengabulkan atau menolak permohonan grasi yang diajukan terpidana setelah mendapat pertimbangan dari MA. Pemberian grasi oleh Presiden dapat berupa:

a) Peringanan atau perubahan jenis pidana;

b) Pengurangan jumlah pidana; atau

c) Penghapusan pelaksanaan pidana.
GAAR memerlukan kejelasan dalam pelaksanaannya, dampak dari hukuman mati yang tidak dilakukan dirasakan oleh Lapas. Sebagai contoh, di Lapas porong masih ada terpidana mati yang belum dieksekusi padahal sudah menghuni Lapas selama 20 tahun hingga 22 tahun. Bahkan, ada terpidana mati di Lapas yang telah mengalami gangguan jiwa berat, sehingga keberadaannya malah mempersulit aktifitas di Lapas. Permasalahan dalam pelaksanaan eksekusi pidana mati yaitu pada waktu pelaksanaannya. Dalam Penetapan Presiden No.2/PNPS/1964 tentang Tata Cara Pelaksanaan Pidana Mati yang Dijatuhkan oleh Pengadilan di Lingkungan Umum dan Militer tidak diatur dengan jelas kapan waktu pelaksanaan hukuman mati. Pengaturan tentang waktu hanya mengatur tentang pemberitahuan kepada terpidana dan terhadap terpidana yang sedang hamil. Terpidana mengetahui pidana mati akan dilaksanakan yaitu tiga kali dua puluh empat jam sebelum dilaksanakan.

Jika persyaratan pidana yang dapat diajukan grasi sebagaimana tersebut dalam Pasal 2 Ayat (2) UU RI No.22 Tahun 2002 dan Pasal 12 Ayat (1) Peraturan Menteri Hukum Dan Hak Asasi Manusia Republik Indonesia Nomor 49 Tahun 2016, maka Presiden hanya akan disibukkan dengan mengurusi grasi. Kondisi praktik yang sering menimbulkan polemik, antara lain: Dalam format Keppres, misalnya pemberian grasi kepada Corby dan Grobmann, tidak disebutkan apa yang menjadi dasar pemikiran dan pertimbangan MA untuk merekomendasikan mengabulkan permohonan grasi. Dalam praktik, seringkali alasan yang disebutkan hanya berupa 'terdapat cukup alasan untuk memberikan grasi kepada terpidana tersebut'. Dalam sejumlah praktik, presiden selain mendapatkan pertimbangan MA, juga mendapatkan pertimbangan Jaksa Agung dan Menteri Hukum dan HAM. Kondisi praktik yang menimbulkan polemik diatas menunjukkan bahwa: kurang transparan dan akuntabel dalam alasan pemberian grasi, kurang transparan release data berapa grasi yang diterima dan ditolak Ketidakjelasan frase tentang "kepentingan Negara".

\section{Amnesti}

Apabila merujuk pada kamus hukum yang ditulis oleh Marwan dan Jimmy, definisinya sbb: amnesti adalah pernyataan umum yang diterbitkan melalui atau dengan UU tentang pencabutan semua akibat dari pemindanaan suatu perbuatan pidana 
tertentu atau satu kelompok perbuatan pidana. ${ }^{15}$

Dalam kaitannya dengan hukum pidana, kewenangan memberikan amnesti yang dimiliki Presiden ini sesungguhnya berbicara tentang hapusnya kewajiban seseorang menjalani pidana, khususnya berkaitan dengan alasan pemaaf dalam hukum pidana.

Dengan pemberian amnesti sesungguhnya Presiden menyatakan bahwa sifat melawan hukum dari perbuatan seseorang ditiadakan karena Presiden mempergunakan hak nya memaafkan perbuatan melawan hukum yang dilakukan oleh seseorang dan sekelompok orang. Berbeda dengan amnesti, berkaitan dengan hak abolisi, jika dipotret dari teori hukum pidana maka hak ini mempunyai kesamaan ide dengan hapusnya hak menuntut yang dikenal di dalam KUHP.

Berkaitan dengan hapusnya hak menuntut di dalam KUHP, secara umum penuntutan dihentikan atau dicabut apabila 1. Telah ada putusan hakim yang tetap (de kracht van een rechter lijkgeweijsde) mengenai tindakan yang sama (Pasal 76). 2. Terdakwa meninggal dunia (Pasal 77). 3. Perkara telah kadaluarsa (Pasal 78). 4. Terjadi penyelesaian di luar pengadilan (Pasal 82). Pasal 4 UU 11 Tahun 1954 menyatakan bahwa dengan pemberian amnesti semua akibat hukum pidana terhadap orang-orang diberikan amnesti dihapuskan.

Sedangkan untuk pemberian abolisi maka penuntutan terhadap orang-orang yang diberikan abolisi ditiadakan. Amnesti dan abolisi pernah dilaksanakan sebagaimana dalam UU Darurat No. 11 Tahun 1954 sehubungan pada saat itu terjadinya sengketa politik antara Indonesia (Yogyakarta) dengan Kerajaan Belanda (pasal 2). UU ini merupakan pelaksanaan dari UUD Sementara Tahun 1950. Menurut ketentuan pasal 1, Presiden memberikan amnesti atau abolisi dengan pertimbangan dari MA berdasarkan permintaan dari Menteri Kehakiman.

Dalam hal aturan pelaksana dari ketentuan ini perlu diteliti lebih lanjut. Dengan adanya Pasal 14 ayat (2) UUD 1945 yang mengatur lembaga yang memberikan pertimbangan kepada Presiden berbeda, maka ketentuan pasal 1 UU Darurat 1954 tidak berlaku lagi, namun demikian belum diatur bagaimana proses pelaksanaan amesti dan abolisi sebagai implementasi dari ketentuan pasal 14 ayat (2) UUD 1945 tersebut. "Kepentingan Negara" yang tercantum dalam UUD 1945 dalam pemberian amnesti diterjemahkan dalam konteks

15 M. Marwan dan Jimmy P, Kamus Hukum (Surabaya: Reality Publisher, 2009). politik. UU amnesti dan abolisi sendiri tidak menjelaskan kriteria apa yang dimaksud dengan kepentingan negara. kedua aturan yang ada terkait pemberian amnesti dari Presiden, memberikan petunjuk yang berbeda terkait mekanisme yang harus dijalani.

UU amnesti dan abolisi mengatakan presiden dapat memberikan amnesti setelah mendapat nasihat tertulis dan MA yang diminta terlebih dulu oleh kementerian terkait (dalam hal ini Kementerian Hukum dan Hak Asasi Manusia). Menurut UUD 1945 pasal 14 ayat 2, pemberian amnesti Presiden harus dengan pertimbangan DPR. mekanisme yang jelas terkait pemberian amnesti dari Presiden. Selain itu, aturan hukum yang baru juga harus memperjelas definisi dan indikator kepentingan negara dengan jelas. Hal ini akan memudahkan Presiden dalam menggunakan hak prerogratifnya. Selain itu, DPR serta masyarakat juga bisa mengawasi jalannya pemberian amnesti oleh Presiden karena batasan-batasannya sudah jelas. Belum menemukan peraturan perundangundangan tentang prosedur baku yang mengatur mengenai tata cara pemberian Amnesti.

a) Perlu adanya peraturn perundang-undangan yang mengatur tentang mekanisme pemberian amnesti, dan kami memberi masukan sebagai berikut:

b) Berdasarkan telaahan/ kajian dari Menteri yang membidangi Politik, Hukum dan HAM, usul amnesti disampaikan kepada Presiden.

c) Presiden meminta pertimbangan kepada DPR dan selanjutnya membuat keputusan.

\section{Abolisi}

Apabila merujuk pada kamus hukum yang ditulis oleh Marwan dan Jimmy, definisinya sbb: abolisi adalah suatu hak untuk menghapuskan seluruh akibat dari penjatuhan putusan pengadilan atau menghapuskan tuntutan pidana kepada seorang terpidana, serta melakukan penghentian apabila putusan tersebut telah dijalankan. Merupakan hak prerogatif Presiden yang hanya diberikan setelah meminta nasihat MA. ${ }^{16}$

Presiden, atas kepentingan Negara, dapat memberi amnesti dan abolisi kepada orang-orang yang telah melakukan sesuatu tindakan pidana. Presiden memberi amnesti dan abolisi ini setelah mendapat nasihat tertulis dari MA yang menyampaikan nasihat itu atas permintaan Menteri Kehakiman (saat ini Menteri Hukum dan HAM). Apabila merujuk ada Pasal 2, amnesti dan abolisi

16 Ibid. 
diberikan kepada semua orang yang sebelum tanggal 27 Desember 1949 telah melakukan sesuatu tindak pidana yang nyata akibat dari persengketaan politik antara Republik Indonesia (Yogyakarta) dan Kerajaan Belanda. Apabila memahami substansi tersebut, dapat ditarik kesimpulan bahwa amnesti dan abolisi berlaku sebelum 27 Desember 1949.

Pada saat penelitian belum menemukan peraturan perundang-undangan tentang prosedur baku yang mengatur mengenai tata cara pemberian abolisi. Perlu adanya peraturan perundangundangan yang mengatur tentang mekanisme pemberian abolisi yang dapat diajukan permohonan abolisi adalah hanya terhadap seluruh proses pemeriksaan yang sedang berjalan sebelum pengadilan menjatuhkan keputusan terhadap perkara tersebut. Alasan abolisi harus berdasarkan pada pertimbangan bahwa dengan melakukan proses hukum kepada tersangka atau terdakwa akan merugikan kepentingan umum atau kepentingan Negara.

\section{Rehabilitasi}

Presiden memberikan rehabilitasi kepada seseorang dengan memperhatikan pertimbangan MA. Dalam penjelasan umum KUHAP menyatakan bahwa rehabilitasi atau ganti kerugian diberikan kepada seorang yang ditangkap, ditahan, dituntut ataupun diadili tanpa alasan yang berdasarkan UU dan atau karena kekeliruan mengenai orangnya atau hukum yang diterapkan.

Ganti kerugian dan rehabilitasi diberikan sejak tingkat penyidikan dan para pejabat penegak hukum, yang dengan sengaja atau karena kelalaiannya menyebabkan asas hukum tersebut dilanggar, dituntut, dipidana dan atau dikenakan hukuman administrasi. Presiden memberikan rehabilitasi kepada seseorang dengan memperhatikan pertimbangan MA

Dalam penjelasan umum KUHAP menyatakan bahwa rehabilitasi atau ganti kerugian diberikan kepada seorang yang ditangkap, ditahan, dituntut ataupun diadili tanpa alasan yang berdasarkan UU dan atau karena kekeliruan mengenai orangnya atau hukum yang diterapkan.

Ganti kerugian dan rehabilitasi diberikan sejak tingkat penyidikan dan para pejabat penegak hukum, yang dengan sengaja atau karena kelalaiannya menyebabkan asas hukum tersebut dilanggar, dituntut, dipidana dan atau dikenakan hukuman administrasi.

17 Mosgan Situmorang, "Problematika Merehabilitasi Kedudukan Orang Yang Tersangkut Pidana Pada
Yang dapat diajukan permohonan rehabilitasi kepada Presiden adalah hanya terhadap seorang yang telah mendapat keputusan grasi atau abolisi. Rehabilitasi hanya diberikan kepada seseorang yang sudah mendapatkan keputusan penghapusan proses hukum (abolisi). Pemberian GAAR harus diberikan secara sangat selektif karena akan berdampak kepada kewibawaan negara dan kewibawaan hukum.

Seseorang memiliki hak untuk mendapatkan rehabilitasi pada saat:

a) Mengajukan rehabilitasi melalui praperadilan, akibat tidak sahnya penangkapan atau penahan atau akibat sahnya penghentian penyidikan atau penuntutan termasuk penetapan tersangka, penggeledahan, dan penyitaan yang diajukan oleh tersangka atau pihak ketiga yang berkepentingan;

b) Apabila diputus bebas atau diputus lepas dari segala tuntutan hukum yang putusannya telah mempunyai kekuatan hukum tetap, rehabilitasi tersebut diberikan dan dicantumkan sekaligus dalam putusan pengadilan.

Agar pengaturan rehabilitasi untuk mengembalikan kedudukan atau jabatan yang sempat hilang lebih efektif maka harus diadakan perubahan terhadap peraturan yang menjadi dasar pelaksanaannya khususnya Peraturan Pemerintah Nomor 27 Tahun 1983 Peraturan Pemerintah Nomor 27 Tentang pelaksaan KUHAP yang sudah diubah dua kali, terakhir dengan Peraturan Pemerintah 92 Tahun 2015. Perubahan tersebut dimaksudkan agar peraturan tersebut lebih mudah diimplementasikan. ${ }^{17}$

Keadaan Semula," Jurnal Penelitian Hukum De Jure 19, no. 2 (2019): 151. 
Tabel.1 Hak Prerogatif Presiden

\begin{tabular}{|c|c|c|c|c|}
\hline & Grasi & Amnesti & Abolisi & Rehabilitasi \\
\hline $\begin{array}{l}\text { Dasar } \\
\text { Hukum }\end{array}$ & $\begin{array}{l}\text { Pasal } 14 \text { UUD } \\
1945 \text { dan UU No. } \\
22 \text { Tahun } 2002 \\
\text { tentang Grasi jo } \\
\text { UU No. } 5 \text { Tahun } \\
2010 \text { tentang } \\
\text { Perubahan atas } \\
\text { UU No. 22 Tahun } \\
2002 \text { tentang } \\
\text { Grasi ("UU } \\
\text { Grasi") }\end{array}$ & 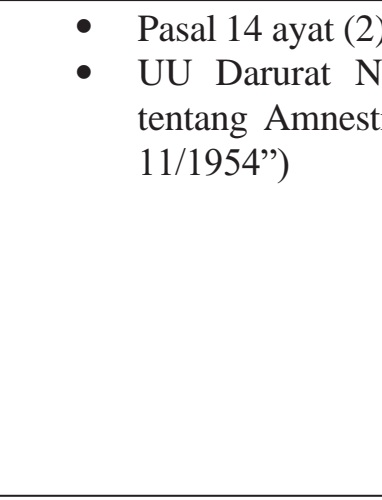 & $\begin{array}{l}\text { UUD } 1945 \\
\text { o. } 11 \text { Tahun } 1954 \\
\text { dan Abolisi ("UU }\end{array}$ & $\begin{array}{ll}\text { - } & \text { pasal 14 ayat 1 } \\
& \text { UUD } 1945 \\
\text { - } & \text { Pasal } 1 \text { angka } 23 \\
\text { - } & \text { Pasal } 95 \text { serta Pasal } \\
& 97 \text { UU No. } 8 \text { Tahun } \\
& 1981 \text { tentang } \\
\text { KUHAP } \\
\text { PP No. 27/1983 } \\
\text { tentang Peraturan } \\
\text { Pelaksanaan } \\
\text { KUHAP } \\
\end{array}$ \\
\hline $\begin{array}{l}\text { Bentuk } \\
\text { Kewenangan }\end{array}$ & $\begin{array}{l}\text { Pemberian grasi } \\
\text { oleh Presiden } \\
\text { dapat berupa: } \\
\text { peringanan atau } \\
\text { perubahan jenis } \\
\text { pidana; } \\
\text { pengurangan } \\
\text { jumlah pidana; } \\
\text { atau penghapusan } \\
\text { pelaksanaan } \\
\text { pidana }\end{array}$ & $\begin{array}{l}\text { Tindakan } \\
\text { pengampunan yang } \\
\text { diberikan oleh } \\
\text { pemerintah terhadap } \\
\text { tindakantindakan } \\
\text { seseorang khususnya } \\
\text { yang berhubungan } \\
\text { dengan } \\
\text { kegiatankegiatan } \\
\text { politik atau kejahatan } \\
\text { politik pada masa lalu. }\end{array}$ & $\begin{array}{l}\text { Menghentikan } \\
\text { proses } \\
\text { pemeriksaan dan } \\
\text { penuntutan } \\
\text { terhadap seorang } \\
\text { tersangka, atau } \\
\text { pencabutan } \\
\text { tuduhan kriminal } \\
\text { karena } \\
\text { pemeriksaan dan } \\
\text { penuntutan } \\
\text { tersebut dapat } \\
\text { mengganggu } \\
\text { stabilitas } \\
\text { pemerintahan }\end{array}$ & $\begin{array}{l}\text { Memberikan pemulihan } \\
\text { haknya dalam kemampuan, } \\
\text { kedudukan dan harkat serta } \\
\text { martabatnya diadili tanpa } \\
\text { alasan yang berdasarkan } \\
\text { undang-undang atau karena } \\
\text { kekeliruan mengenai } \\
\text { orangnya atau hukum yang } \\
\text { diterapkan menurut cara } \\
\text { yang diatur dalam } \\
\text { undangundang ini }\end{array}$ \\
\hline
\end{tabular}

Sumber: Diolah dari Penelitian,2020

\section{A. Urgensi Pembentukan UU GAAR}

Mengapa penting untuk dilakukan pembentukan RUU GAAR adalah karena UUD 1945 tidak memberi panduan mengenai perkara mana yang bisa masuk dalam konteks grasi, amnesti, abolisi, maupun rehabilitasi. UUD 1945 hanya menyebut soal pertimbangan dari lembagalembaga lain. Pengaturan dalam UU yang ada didasarkan pada doktrin mengenai apa itu GAAR. Namun doktrin juga mengalami perkembangan dan pembaruan, sehingga perlu ada aturan main yang lebih jelas, karena selalu akan ada pilihan forum yang digunakan. ${ }^{18}$

Contohnya dalam kasus Baiq Nuril, waktu itu terjadi kebingungan, apakah amnesti bisa diberikan kepada kasus individual, karena ada pandangan, penerapannya biasanya hanya untuk kelompok. Pandangan ini lahir dari kasus-kasus besar pada lalu, yang juga menjadi konteks politik dikeluarkannya UU No. 11 Tahun 1954 tentang

18 Bivitri Susanti, "Focus Group Discussion (FGD) 'Urgensi Perubahan Undang-Undang Di Bidang Grasi, Amnesti, Abolisi Dan Rehabilitasi'”' (Jakarta:
Amnesti dan Abolisi. Namun demikian, sesungguhnya tidak ada pembatasan eksplisit dalam peraturan perundang-undangan mengenai kelompok atau individu.

Karena itu pula, pada awal reformasi misalnya, Budiman Sudjatmiko yang divonis 13 tahun penjara atas tuduhan makar kemudian diberikan amnesti oleh Presiden Abdurrahman Wahid. Dengan demikian, argumen bahwa amnesti tidak dapat diberikan pada Nuril karena ia hanya seorang individu, bukan bagian dari kelompok, merupakan argumen yang keliru. Selanjutnya, dari kasus-kasus yang ada, bahkan yang melibakan individu yang diberikan amnesti seperti disebut di atas, ada pandangan kuat bahwa amnesti hanya diberikan pada narapidana politik (napol), sementara Nuril bukanlah Napol.

Terdapat 2 (dua) alasan mengapa kasus Baiq Nuril sangat kuat berdimensi politik, Pertama, pemerintah sebenarnya sudah sejak 1984 (paling tidak secara legal formal ditunjukkan dengan

Kementerian Hukum dan HAM RI, Dirjen Administrasi Hukum dan HAM, 2020). 
meratifikasi CEDAW) sudah berkomitmen untuk menghapus diskriminasi terhadap perempuan. Komitmen ini kemudian diwujudkan dalam berbagai kebijakan gender, maupun pemenuhan dan perlindungan hak-hak perempuan. Sehingga diberikannya Amnesti terhadap Nuril merupakan langkah politik yang penting bagi pemerintah untuk menguatkan kembali komitmen ini dan menunjukkannya secara luas kepada publik.

Kedua, ditunjukkannya komitmen tersebut juga menjadi penting sementara pembahasan RUU Penghapusan Kekerasan Seksual masih terhambat di DPR. Penting bagi pemerintah untuk menunjukkan komitmennya terhadap penghapusan kekerasan seksual dalam kasus konkrit seperti ini sementara RUU PKS yang sangat didukung oleh pemerintah masih belum bisa disetujui. Sedangkan amnesti dan abolisi tidak diatur definisinya dalam UU. Yang digunakan dalam praktik adalah pemahaman doktrinal dan kontekstual dari UU No.

11 Tahun 1954 tersebut. Rehabilitasi diatur definisinya dalam ketentuan umum KUHAP dengan baik. Pengaturan mengenai objek GAAR harus diatur dengan rinci agar operasional.

Akhiar Salimi berpendapat, terkait dengan urgensi pembentukan RUU GAAR didasari alasan bahwa hukum merupakan kristalisasi dari nilai nilai yang hidup dalam masyarakat yang selalu berubah. Oleh karena itu, hukum juga perlu dirubah sesuai dengan kebutuhan masyarakat. Sampai saat ini, baru Grasi dan Amnesti serta Abolisi yang sudah diatur lebih lanjut dalam UU. ${ }^{19}$

Sedangkan tentang Rehabilitasi belum ada pengaturannya secara khusus di dalam satu UU. Rehabilitasi hanya "ditempelkan" dalam UU No.8 Tahun 1981 tentang Hukum Acara Pidana. Muncul pertanyaan apakah rehabilitasi yang diatur dalam pasal 97 KUHAP ini sama yang dimaksud dengan rehabilitasi yang diatur dalam pasal 14 ayat (1) UUD 1945 atau bukan. UU No. 22 Tahun 2002 jo UU No. 5 Tahun 2010 pengaturannya sangat sederhana dan sudah tidak sesuai lagi dengan perkembangan zaman.

UU Darurat No. 11 Tahun 1954 yang mengatur tentang Amnesti dan Abolisi, pengaturannya lebih summier lagi jika dibandingkan dengan UU No. 22 Tahun 2002 jo UU No. 5 Tahun 2010, hanya terdiri dari 5 pasal. Definisi tentang amnesti dan abolisi saja tidak

19 Akhiar Salmi, "Focus Group Discussion (FGD) 'Urgensi Perubahan Undang-Undang Di Bidang Grasi, Amnesti, Abolisi Dan Rehabilitasi"' (Jakarta: Kementerian Hukum dan HAM RI, Dirjen Administrasi Hukum dan HAM, 2020). diatur. Mungkin ini merupakan bukti UU itu dibuat secara darurat. Lagi pula, UU ini didasarkan kepada UUDS 1950.

\section{Adanya Putusan MK No. 107/PUU- XIII/2015 \\ Menjadi alasan pentingnya dibentuknya} RUU GAAR. Melalui putusan tersebut yang terdapat dalam amar putusanya MK mengabulkan permohononan pemohon seluruhnya, menyatakan Pasal 7 ayat (2) UU No. 5 Tahun 2010 tentang Perubahan Atas UU No. 22 Tahun 2002 tentang Grasi bertentangan dengan UUD 1945 dan tidak mempunyai kekuatan hukum mengikat. Putusan tersebut memiliki dampak pada perubahan jangka waktu dalam pengajuan permohonan grasi yang sebelumnya paling lama satu tahun setelah putusan berkekuatan hukum tetap menjadi tidak dibatasi oleh waktu. Keunikan putusan MK terletak pada sifatnya yang relatif atau tidak mempunyai kekuatan hukum mengikat bagi MPR untuk mengikuti putusan MK, kecuali dalam hal penyelenggaraan rapat paripurna sebagaimana usulan Dewan Perwakilan Rakyat. ${ }^{20}$

Jika melihat pada Pasal 27 (1) UUD Tahun 1945 yang menyatakan bahwa "Segala warga negara bersamaan kedudukannya di dalam hukum dan pemerintahan dan wajib menjunjung hukum dan pemerintahan itu dengan tidak ada kecualinya." Serta makna konsep equality before of the law bahwa kesamaan di hadapan hukum berarti setiap warga negara harus diperlakukan adil oleh aparat penegak hukum dan pemerintah, maka pembatasan pada Pasal 2 (2) yang menyatakan pidana penjara paling rendah 2 tahun tidak mencerminkan pada makna yang terkandung dalam UUD 1945 dan dasar hukum konsep equality before of the law. Sebaiknya kalimat dalam Pasal 2 (2) paling rendah 2 tahun dihapus. Kewenangan untuk menolak dan menerima grasi adalah Hak Prerogatif dari Presiden, jangan dibatasi hanya terhadap putusan pidana penjara paling rendah 2 tahun saja untuk yang di bawah 2 tahun pun semestinya dapat mempunyai hak untuk melakukan grasi.

20 Andryan Farid Wajdi, "Konstitusi Terhadap, Sifat Putusan Impeachment Mahkamah Status Hukum Presiden Dan/Atau Wakil Presiden," Jurnal Penelitian Hukum De Jure 20, no. 10 (2020): 301314. 


\section{UU Darurat No 11 Tahun 1954 Tentang Amnesti dan Abolisi bersifat Einmaligh}

UU Darurat No.11 Tahun 1954 tentang Amnesti dan Abolisi yang dikeluarkan pada masa Republik Idonesia Serikat diperuntukan kepada semua orang yang sebelum tanggal 27 Desember 1949 telah melakukan suatu tindak pidana yang nyata akibat dari persengketaan politik antara Republik Indonesia dan Kerajaan Belanda (Pasal 2 UU Darurat No.11 tahun 1954). UU darurat ini bersifat einmaligh yaitu bersifat sekali selesai, namun sampai saat ini UU tersebut belum pernah di cabut.

\section{Adanya Kebutuhan Hukum dan Perubahan Ketatanegaraan}

Kebutuhan hukum yang dimaksud adalah Kasus Baiq Nuril berdasarkan putusan kasasi MA menolak peninjauan kembali mantan tenaga honorer SMAN 7 Mataram, Baiq Nuril Maknum, dalam kasus penyebaran konten bermuatan asusila. Artinya, Baiq Nuril tetap diputus bersalah sehingga harus menjalani hukum 6 bulan penjara dan denda Rp 500 juta karena melanggar Pasal 27 Ayat (1) UU ITE.

Padahal banyak kalangan yang menilai bahwa putusan ini tidak mencerminkan rasa keadilan dan tidak adanya perlindungan negara kepada warga negara seperti pada Baiq Nuril. Seperti yang diketahui Bersama berdasarkan putusan Pengadilan Negeri Mataram Baiq Nuril dinyatakan bebas dan tidak bersalah. Skala keadilan sangat bervariasi dari satu tempat ke tempat lain, setiap skala didefinisikan dan sepenuhnya ditentukan oleh masyarakat sesuai dengan ketertiban umum dari masyarakat tersebut. $^{21}$

\section{Belum Adanya UU Rehabilitasi}

Sampai dengan saat ini belum terdapat UU yang mengatur tentang pemberian rehabilitasi seperti halnya UU Grasi. Belum adanya dasar hukum tentang rehabilitasi tentu saja menjadi suatu kendala tersendiri bagi Sekretariat Negara dalam memberikan dukungan teknis dan analisis penyelesaian rancangan Keputusan Presiden mengenai rehabilitasi.

Sedangkan untuk amnesti dan abolisi diatur didalam UU Darurat Republik Indonesia No. 11 Tahun 1954 Tentang Amnesti dan Abolisi. Berdasarkan Pasal 1 UU Darurat tersebut mengatur

21 Agus Santoso, Hukum,Moral \& Keadilan Sebuah Kajian Filsafat Hukum, Ctk. Kedua. (Jakarta: Kencana, 2014). tentang Amnesti dan Abolisi, pengaturannya lebih summier lagi jika dibandingkan dengan UU No. 22 Tahun 2002 jo UU No. 5 Tahun 2010, hanya terdiri dari 5 pasal. Definisi tentang amnesti dan abolisi saja tidak diatur. Mungkin ini merupakan bukti UU itu dibuat secara darurat. Lagi pula, UU ini didasarkan kepada UUDS 1950.

\section{Kurang Transparan dan Akuntabel}

Kondisi praktik yang sering menimbulkan polemik dalam praktek pemberian grasi, antara lain: pertama, dalam format Keputusan Presiden, misalnya pemberian grasi kepada Corby dan Grobmann, tidak disebutkan apa yang menjadi dasar pemikiran dan pertimbangan MA untuk merekomendasikan mengabulkan permohonan grasi, kedua, dalam praktik, seringkali alasan yang disebutkan hanya berupa 'terdapat cukup alasan untuk memberikan grasi kepada terpidana tersebut'. Ketiga, dalam sejumlah praktik, presiden selain mendapatkan pertimbangan MA, juga mendapatkan pertimbangan Jaksa Agung dan Menteri Hukum dan HAM.

Kondisi praktik yang menimbulkan polemik diatas menunjukkan bahwa dalam pemberian grasi kurang transparan dan akuntabel dalam pemberian grasi dan kurang transparan release data berapa grasi yang diterima dan ditolak. Juga ketidakjelasan frase tentang "kepentingan negara", yang tercantum dalam UUD 1945 dalam pemberian amnesti diterjemahkan dalam konteks politik. UU amnesti dan abolisi sendiri tidak menjelaskan kriteria apa yang dimaksud dengan kepentingan Negara.

\section{UU GAAR Existing Kurang Sistematis dan Peninggalan Kolonial}

Setidaknya terdapat alasan sistematis terkait dengan urgensi pembentukan RUU GAAR. Pertama, persoalan pengaturan GAAR dalam beberapa UU dengan konteks waktu pembentukan yang berbeda-beda sehingga kurang sistematis baik dari konsep (istilah) yang digunakan, proses maupun konteks sosial. Kedua, UU yang ada sekarang sudah tidak sesuai dengan kebutuhan hukum masyarakat karena pengaturan GAAR masih peninggalan kolonial. 


\section{Tidak Adanya Norma, Kualifikasi dan Waktu pada UU Grasi}

Turunan pengaturan grasi dalam UUD 1945 diatur dalam UU No. 22 Tahun 2002 tentang Grasi sebagaimana telah diubah dengan UU No. 5 Tahun 2010 tentang Perubahan Atas UU No. 22 Tahun 2002 tentang Grasi. Dalam Pasal 1 ayat 1 UU Grasi disebutkan definisi Grasi adalah pengampunan berupa perubahan, peringanan, pengurangan, atau penghapusan pelaksanaan pidana kepada terpidana yang diberikan oleh Presiden. Dalam UU Grasi tidak diatur norma kualifikasi tindak pidana apa yang dapat diberikan grasi. Apakah pidana tertentu menyangkut extra ordinary crime seperti korupsi, narkotika bahkan genosida juga dapat diberikan grasi.

Dalam UU grasi ternyata ada hal yang pengaturannya tidak tegas, yaitu mengenai tidak ada pembatasan waktu bagi pemohon grasi. Untuk putusan yang berupa pidana penjara seumur hidup, pidana penjara sementara waktu, dengan tidak adanya pembatasan waktu tersebut tidak akan berpengaruh pada pelaksanaan putusan, tetapi untuk terpidana mati eksekusinya harus menunggu putusan penolakan grasi dari Presiden. Ketidakjelasan pengaturan tersebut dapat dimanfaatkan oleh terpidana mati untuk menunda eksekusi hukuman.

\section{Regulasi Darurat Amenesti dan Abolisi Sudah Tidak Berlaku}

Sedangkan untuk amnesti dan abolisi, diatur dalam UU Darurat No. 11 Tahun 1954 tentang Amnesti dan Abolisi. Regulasi darurat ini sebenarnya sudah tidak berlaku, sebab norma konstitusi yang menjadi rujukannya sudah gugur dengan Pasal 14 UUD 1945 setelah amandemen. Dilihat dari sejarahnya UU Darurat ini adalah pelaksana dari Pasal 107 UUDS 1950 yang mana konstitusi tersebut sudah tidak berlaku lagi sejak Dekrit Presiden 5 Juli 1959. Dalam Pasal 107 konstitusi sementara tersebut disebutkan bahwa pemberian amnesti, abolisi dan grasi harus dengan kuasa UU dan meminta pendapat MA. Maka ditindaklanjuti dengan lahirnya UU Darurat No. 11 Tahun 1954 tentang Amnesti dan Abolisi. Maka perlu dibentuk UU yang mengatur tentang GAAR

\section{Perlunya Relaksasi Permohonan Grasi}

Dalam pemberian grasi, sebelumnya terdapat UU No. 3 Tahun 1950 tentang Permohonan Grasi yang kemudian dicabut dengan UU No. 22 Tahun 2002 jo UU No. 5 Tahun 2010. Dalam prekembangannya dibutuhkan relaksasi atau pelonggaran atas permohonan grasi dalam hal jenis perbuatan dan besaran pidana guna menjamin hak asas manusia (kasus Baiq Nuril).

\section{Potensi Diharmonisasi Antar Peraturan}

GAAR diatur dalam UU yang berbeda walaupun berasal dari sumber yang sama yakni Pasal 14 UUD 1945, bahkan khusus untuk rehabilitasi, belum diatur sama sekali dalam UU. Berdasarkan konsep pengharmonisasian peraturan perundang-undangan maka potensi disharmonisasi antar peraturan perundang-undangan tersebut sangat besar apabila pengaturan dilakukan secara terpisah dalam UU yang berbeda. Sehingga perlu dilakukan kodifikasi atau penyatuan pengaturan dalam satu RUU yang mengatur secara detail berkaitan dengan amanat Pasal 14 UUD 1945. Sebaiknya pengaturan yang merupakan penyatuan dari substansi ketentuan GAAR ini memuat secara jelas hal-hal yang berkaitan dengan kriteria, persyaratan, jangka waktu pengajuan, dan proses pengajuan. Hal ini penting untuk diatur agar tidak menimbulkan multiinterpretasi dan multitafsir dalam praktek pelaksanaan pemberian GAAR. Sehingga hak preogratif Presiden yang terdapat dalam Pasal 14 UUD 1945 tersebut dapat diatur dengan baik dan tidak menimbulkan perdebatan hukum dalam penerapannya

Berdasarkan beberapa penjelasan diatas maka dapat di kelompokkan kedalam 2 substansi alasan mengapa sebuah UU perlu dibentuk, pertama, karena adanya kebutuhan hukum masyarakat dan kedua, karena adanya perubahan ketatanegaraan.

\section{Kebutuhan Hukum Masyarakat}

Dalam hal kebutuhan hukum masyarakat, dari berbagai pendapat yang dihimpun dari narasumber di provinsi Sumatera Barat, Jawa Timur dan DKI Jakarta dapat dipilah dalam beberapa pertimbangan perlunya dilakukan perubahan tentang undang-undang dibidang GAAR.

Pertama, UUD 1945 tidak memberi panduan mengenai perkara mana yang bisa masuk dalam konteks grasi, amnesti, abolisi, maupun rehabilitasi. UUD 1945 hanya menyebut soal pertimbangan dari lembaga-lembaga lain. Hal ini terlihat pada kasus Baiq Nuril terjadi perbedaan pendapat diantara kalangan ahli hukum, apakah Baiq Nuril yang divonis hukuman 6 bulan penjara dan denda 500 juta karena didakwa melanggar UU ITE dapat diberikan amnesti oleh Presiden, karena dalam kasasi MK menolak Pengajuan kembali yang diajukan oleh Baiq Nuril. 
Vonis terhadap Baiq Nuril ini dianggap mencederai rasa keadilan masyarakat. Dalam sepanjang sejarah praktek pemberian amnesti diperuntukkan untuk tindak pidana yang tergolong tindak pidana politik, dan hal ini sesuai dengan bunyi Pasal 2 Amnesti dan abolisi diberikan kepada semua orang yang sebelum tanggal 27 Desember 1949 telah melakukan sesuatu tindak pidana yang nyata akibat dari persengketaan politik antara Republik Indonesia (Yogyakarta) dan Kerajaan Belanda. Kemudian belum ada pendefinisian yang jelas tentang amnesti, abolisi dan Rahabilitasi.

Pengaturan mengenai objek GAAR harus diatur dengan rinci agar operasional. Model pengaturan di dalam UU grasi bisa menjadi model, yang menjelaskan dengan rinci mengenai minimum sanksi pidana misalnya namun demikian, jangan sampai pembatasan ini akan membuat hak prerogatif GAAR menjadi tidak operasional dan tidak bisa digunakan untuk mencapai tujuan sesungguhnya untuk kepentingan politik.

Kedua, dalam praktek pemberian grasi belum terdapat ukuran objektif untuk menjadi acuan bagi presiden untuk menerima atau menolak permohonan grasi yang diajukan karena didalam Keputusan Presiden tentang penolakan ataupun mengabulkan permohonan grasi tidak dimuat dasar pertimbangan MA untuk menolak ataupun menerima permohonan grasi tersebut sehingga masyarakat berpendapat bahwa proses pemberian grasi kurang transparan.

Ketiga, pengaturan hak prerogratif presiden di bidang GAAR perlu dibentuk dalam UU karena UU merupakan regulasi yang bersifat mengikat secara umum (erga omnes) dan UU tersebut bertujuan memberikan norma standar, prosedur dan kriteria atas GAAR.

Keempat adalah konsekuensi Indonesia sebagai negara hukum sebagaimana tertuang didalam Pasal 1 ayat (3) UUD 1945, Indonesia adalah Negara hukum, dalam bingkai Negara hukum, paling tidak di dalamnya akan terkandung ciri-ciri sebagal berikut; (a): kekuasaannya dijalankan sesuai dengan hukum-positif yang berlaku, (b) kegiatan negara berada dl bawah kontrol kekuasaan kehakiman yang efektif, (c) berdasarkan sebuah undang-undang dasar yang menjamin hakhak asasi manusia, (d) adanya pembagian kekuasaan.240 Dalam kaitannya dengan ciri-ciri tersebut diatas, dapat dikatakan bahwa pemberian amnesti dan abolisi serta grasi (sebelum tahun 2002) dilaksanakan tanpa adanya ketentuan "hukum positif", meskipun dilaksanakan berdasarkan sebuah UUD yang menjamin hak-hak asasi manusia

Serta Kelima, berdasarkan konsep pengharmonisasian peraturan perundangundangan maka potensi disharmonisasi peraturan perundang-undangan di bidang GAAR sangat besar apabila pengaturan dilakukan secara terpisah dalam UU yang berbeda. Sehingga perlu dilakukan kodifikasi atau penyatuan pengaturan dalam satu RUU yang mengatur secara detail berkaitan dengan amanat Pasal 14 UUD 1945. Sebaiknya pengaturan yang merupakan penyatuan dari substansi ketentuan GAAR ini memuat secara jelas hal-hal yang berkaitan dengan kriteria, persyaratan, jangka waktu pengajuan, dan proses pengajuan. Hal ini penting untuk diatur agar tidak menimbulkan multiinterpretasi dan multitafsir dalam praktek pelaksanaan pemberian GAAR. Sehingga hak preogratif Presiden yang terdapat dalam Pasal 14 UUD 1945 tersebut dapat diatur dengan baik dan tidak menimbulkan perdebatan hukum hingga menjadi polemic dalam implementasinya.

\section{Adanya Perubahan Ketatanegaraan}

GAAR merupakan hak prerogratif presiden yang diatur didalam Pasal 14 ayat (1) dan (2) UUD 1945. Dalam konteks perubahan ketatanegaraan, UU grasi yang saat ini diatur didalam UU No. 5 Tahun 2010 Tentang Perubahan UU No. 22 Tahun 2002 Tentang Grasi didalam konsidern mengingat sudah mengacu kepada Pasal 14 UUD 1945, namun pada tanggal 15 Juni tahun 2016, MK, melalui putusan No. 107/PUU-XIII/2015, menyatakan Pasal 7 ayat (2) UU No. 5 Tahun 2010 bertentangan dengan UUD 1945 dan tidak mempunyai keputusan hukum yang mengikat.

Keputusan MK ini tentu saja merupakan salah satu bentuk perubahan ketatanegaraan dalam sebuah keberlakuan norma yang ada didalam sebuah UU. Menurut Maruara Siahaan dalam bukunya Hukum Acara MK, mengatakan bahwa putusan MK meniadakan suatu keadaan hukum atau menciptakan kewenangan tertentu. ${ }^{22}$ Namun didalam Putusan Nomor 107/PUU-XIII/2015, dalam amar putusannya tidak menyatakan bahwa Pasal 7 ayat (2) UU No. 22 Tahun 2002 berlaku kembali sebagaimana putusan misalnya Putusan MK No. 28/PUU-XI/2013 mengenai pengujian UU No. 17 Tahun 2012 tentang Perkoperasian terhadap UUD 1945. Dalam amar putusannya Mahkamah

\footnotetext{
22 Maruarar Siahaan, Hukum Acara Mahkamah

Konstitusi (Jakarta: Sinar Grafika, 2012).
} 
Konstitusi menyatakan bahwa UU No. 17 tahun 2012 dinyatakan bertentangan dengan UUD 1945 dan tidak mempunyai kekuatan hukum mengikat.

Selain itu juga didalam amar putusannya MK memutuskan bahwa UU No. 25 Tahun 1992 Tentang Perkoperasian berlaku untuk sementara waktu sampai dengan terbentuknya undangundang yang baru. Dalam konteks uji materi Pasal 7 ayat (2) UU grasi, dimana MK tidak memuat didalam amar putusannya, menyatakan didalam rangka mengisi kekosongan hukum ketentuan didalam Pasal 7 ayat (2) UU No. 22 Tahun 2002 dinyatakan berlaku kembali menunjukkan terjadi kekosongan hukum didalam penerapan Pasal 7 ayat (2) UU No. 5 Tahun 2010 walaupun didalam pertimbangan hukumnya MK berpendapat pembatasan waktu pengajuan permohonan grasi ternyata potensial dapat menghilangkan hak konstitusional terpidana khususnya terpidana mati untuk mengajukan permohonan grasi. Pembatasan demikian juga menghilangkan hak pemohon jika hendak mengajukan upaya hukum luar biasa PK yang persyaratannya salah satunya adalah novum, sedangkan ditemukannya novum ini tidak dapat dipastikan jangka waktunya. ${ }^{23}$

Oleh karena itu dengan adanya keputusan MK yang membatalkan Pasal 7 ayat (2) tentang jangka waktu permohonan grasi merupakan salah satu perubahan ketatanegaraan yang menjadi urgensi terkait dengan pembentukan RUU GAAR. Sedangkan untuk amnesti dan abolisi yang saat ini diatur didalam UU No. 11 Tahun 1954 Tentang Amnesti dan Abolisi sudah tidak sesuai dengan perkembangan ketatanegaraan Indonesia. Didalam UU No. 11 Tahun 1954 didalam konsideren menimbang ditegaskan bahwa UU tentang amnesti dan abolisi diadakan dalam rangka melaksanakan ketentuan dalam Pasal 107 UUDS 1950 dan untuk menyesuaikan Penetapan Presiden Republik Indonesia No. 14 Tahun 1949 Tentang pemberian amnesti.

Selanjutnya didalam konsideren mengingat UU No. 11 Tahun 1954 didasarkan pada Pasal 96 dan 107 UUDS 1950. Saat sekarang ini Konstitusi Negara Republik Indonesia adalah UUD 1945 dan bukan lagi UUDS 1950 sehingga dengan demikian UU No. 11 Tahun 1954 Tentang Amnesti dan Abolisi secara hukum sudah tidak berlaku lagi.

23 Pertimbangan Hukum Mahkamah Konstiyusi, Putusan Mahkamah Kontitusi Nomor 107/PUUXIII/2015, (3.9.5) (2015).

24 Moh. Fajrul Falaakh, “Apakah Keppres Pemberian Grasi Objek TUN?,'” Hukum Online, last modified 2020, accessed January 21, 2021,
Kemudian terdapat ketentuan yang bertentangan yang diatur didalam UU No. 11 Tahun 1954 yaitu didalam Pasal 1 "Presiden memberi amnesti dan abolisi setelah mendapat nasihat tertulis dari MA yang menyampaikan nasihat itu atas permintaan Menteri Kehakiman, sedangkan didalam Pasal 14 ayat (1) Presiden memberi grasi dan rehabilitasi dengan memperhatikan pertimbangan MA. Selain itu, pertimbangan Mahkamah Agung dilaksanakan dalam kaitannya dengan fungsi kepenasihatan (advisory function) di bidang hukum Hal ini tidak sesuai dengan UU No. 12 Tahun 2011 Tentang Pembentukan Peraturan Perundang-undangan. ${ }^{24}$

Didalam Pasal 7 ayat (1) Undang-Undang

Pembentukan Pembentukan Peraturan PerundangUndangan diatur tentang jenis dan hierarki Peraturan Perundang-Undangan yang terdiri atas:

1) UUD Tahun 1945;

2) Ketetapan Majelis Permusyawaratan Rakyat;

3) UU;

4) UU/Peraturan Pemerintah Pengganti Undang-Undang;

5) Peraturan Pemerintah;

6) Peraturan Presiden;

7) Peraturan Daerah Provinsi;

8) Peraturan Daerah Kabupaten/Kota.

Lebih lanjut didalam penjelasan Pasal 7 ayat (2) UU No. 12 Tahun 2011 yang dimaksud dengan "hierarki" adalah penjenjangan setiap jenis peraturan perundang-undangan yang didasarkan pada asas bahwa peraturan perundang-undangan yang lebih rendah tidak boleh bertentangan dengan peraturan perundang-undangan yang lebih tinggi. Dan hal ini sesuai dengan asas hukum lex superior derogate legi inferiori yang bermakna undangundang (norma/aturan hukum) yang lebih tinggi meniadakan keberlakukan UU (norma/aturan hukum) yang lebih rendah. ${ }^{25}$ Sedangkan untuk rehabilitasi yang merupakan hak prerogratif Presiden sebagaimana diatur didalam Pasal 14 ayat (2) UUD 1945 sampai dengan hari ini belum ada UU yang mengaturnya sehingga untuk memberikan acuan bagi presiden dalam mengimplementasikan hak prerogratifnya secara objektif dan bukan subjektif.

https://www.hukumonline.com/klinik/detail/ulasan/ lt4fd2756d2c45d/grasi-presiden/.

25 Nurfaqih Irfani, “Asas Lex Superior, Lex Specialis, Dan Lex Posterior: Pemaknaan, Problematika, Dan Penggunaannya Dalam Penalaran Dan Argumentasi Hukum," Jurnal Legislasi Volume 17 (2020). 
Perlu di cermati adalah hak prerogatif ini merupakan tindakan nyata dalam kehidupan bernegara, yang harus diambil oleh Presiden atas dasar kemanfaatan dan kepentingan publik yang lebih luas karena tidak adanya hukum baik dalam kontitusi maupun UU yang secara tegas mengaturnya. Dengan demikian hak prerogatif mengandung sifat diskresi dalam bidang ketatanegaraan yang tentunya harus memperhatikan persoalan doelmategheid selain rechtmatigheid. ${ }^{26}$

Makna hak prerogatif terakhir inilah dapat dikatakan sebagai pemaknaan hak prerogatif yang paling esensial dan perlu dikembangkan dalam konteks ketatanegaraan Indonesia terutama apabila ada kejadian konkret yang harus segera direspon oleh seorang Presiden, dengan tetap membedakannya dengan prinsip Negara dalam keadaan bahaya maupun kegentingan memaksa di mana presiden dapat mengeluarkan Perppu.

Walau bagaimanapun perkataan Locke yang menyebut "peraturan perundang-undangan tidak mungkin menampung segala permasalahan yang ada dan dapat secara langsung menyediakan solusi terhadap kepentingan publik" patut menjadi acuan, sehingga Presiden Indonesia selayaknya sama seperti apa yang dilakukan Presiden Amerika Serikat, atas dasar kekuasaan yang diberikan kepadanya berhak melakukan tindakan terhadap kondisi ketatanegaraan yang terjadi atas dasar penafsiran terhadap kekuasaan konstitusional yang diberikan UUD 1945 kepadanya, untuk kemudian ia klaim menjadi kewenangan yang harus ia ambil dengan pertimbangan kemanfaatan dan kepentingan publik.

Selanjutnya setelah membahas urgensi pembentukan dilanjutkan dengan pengaturan RUU GAAR, dalam pengaturan ini maka tentunya Roh/ jiwa RUU GAAR diharapkan memiliki konten yang sesuai dengan tujuan mulia (kemanusiaan) untuk dapat menjangkau substansi dari berbagai aspek yang lebih luas, tepat, bermanfaat dan memenuhi rasa keadilan bagi subyek hukum, masyarakat maupun Pemerintah.

Pengaturan dalam beberapa UU tersebut tidak lengkap, terutama mengenai amnesti dan abolisi, bahkan konteks (historis) menuntut untuk dilakukan pembaharuan hukum karena baik alasan filosofis (alasan ideal, seperti perlu tidaknya pembatasan kekuasaan Presiden dalam hal itu atau mutlak), maupun alasan sosiologis (seperti

26 Mei Susanto, "Kajian Putusan Mahkamah Konstitusi Nomor 22 / PUU-XIII / 2015 THE CONSTRUAL DEVELOPMENT An Analysis of Constitutional melepaskan amnesti dan abolisi dari semata-mata berhubungan dengan kasus politik sebagai tergambar dalam sejarahnya di Indonesia).

Termasuk alasan yuridis (hukum), terutama berkaitan dengan sistematisasi. Beberapa hal menunjukkan bahwa pengaturan dalam beberapa UU tersebut mengandung ketidaksinkronan, mulai dari konsep (penggunaan istilah dan pengertiannya), maupun prosedur atau mekanismenya. Prosedur atau mekanisme permohonan GAAR juga tidak kalah pentingnya untuk disinkronkan, baik karena untuk kejelasan maupun adanya standar proses yang sesuai dengan asas sederhana, cepat, dan murah. "Asas sederhana" mensyaratkan prosedur yang pendek permohonan sampai pada Presiden sebagai pemegang hak untuk memberi pengampunan (grasi, amnesti, dan abolisi) atau pemulihan nama baik (rehabilitasi). "Asas cepat" menuntut pembatasan waktu yang rasional, baik dalam hubungan dengan kon pemohon maupun Presiden untuk mempertimbangkan dan mengambil "keputusan", serta MA. Untuk grasi dan rehabilitasi, atau DPR dan untuk amnesti dan abolisi, dalam memberi pertimbangan. Prosedur perlu diperbaiki, pernah ada pengalaman kasus bahwa seorang terpidana harus menunggu hinga berbulan-bulan untuk pertimbangan dari MA keluar, bahkan sampai terpidana meninggal pertimbangan tersebut tidak keluar-keluar.

Oleh karena itu, untuk memberikan rasa keadilan, bentuk kepastian hukum, serta menampung perkembangan dinamika kebutuhan hukum. Langkah-langkah yang bisa dilakukan terkait urgensi perubahan tersebut dapat dilakukan dengan cara:

1. Pemerintah bersama DPR harus melibatkan publik dalam setiap tahapan penyusunannya. Luasnya ruang lingkup GAAR menuntut pihak pembuat UU menjangkau dan melibatkan lebih banyak pemangku kepetingan yang terkait;

2. Pemerintah bersama DPR harus transparan dalam memberikan setiap informasi perkembangan proses perumusan UU ini. Partisipasi dan transparansi ini yang mutlak diperbaiki;

3. Pemerintah bersama DPR harus memetakan regulasi yang berkaitan secara rinci;

4. Pemerintah bersama DPR harus ketat melakukan harmonisasi baik secara vertikal

Court's Decision Number 22 / PUU-XIII / 2015," no. 22 (2017): 237-258. 
dengan peraturan yang lebih tinggi maupun horizontal dengan peraturan yang sederajat;

5. Pemerintah bersama DPR harus melakukan preview serta sosialisasi sebelum disahkan. Hal ini menjadi prioritas untuk menilai dampak yang akan timbul dari UU yang akan disahkan.

\section{KESIMPULAN}

Berdasarkan elaborasi, pembahasan dan analisis yang telah dijabarkan, dapat disimpulkan pembentukan regulasi dibidang GAAR bersifat urgen. Hal karena ini Indonesia dihadapi dengan kompleksnya persoalan hukum serta semakin berkembang berbagai jenis tindak pidana baru, maka regulasi dan peraturan perundang-undangan pun seyogyanya mengikuti perkebangan tersebut.

Sebenarnya dalam menghadapi tindak pidana yang terjadi hukum sudah menyediakan solusinya, namun ada beberapa tindak pidana yang perlu mendapatkan perhatian pemerintah karena memerlukan kehadiran negara dalam mewujudkan rasa keadilan dan perlindungan negara yaitu dengan hak prerogatif Presiden di bidang yudisial dalam hal ini GAAR.

Urgensi pembentukan regulasi dibidang GAAR didasari oleh adanya kebutuhan hukum masyarakat dan adanya perubahan ketatanegaraan. Tujuannya adalah untuk membantu Presiden dalam menggunakan hak prerogatifnya serta untuk memastikan bahwa setiap pengambilan hak prerogatif terdapat asas akuntabilitas, asas transparasi publik sebagai wujud dari good governances.

Yang perlu menjadi perhatian adalah agar tidak tumpang tindih dalam pembentukan RUU GAAR, terlebih dahulu harus mencermati hak prerogatif karena mengandung sifat diskresi dalam bidang ketatanegaraan yang tentunya harus memperhatikan persoalan doelmategheid selain rechtmatigheid. Selain itu juga hak prerogatif inilah paling esensial dan perlu dikembangkan dalam konteks ketatanegaraan Indonesia terutama apabila ada kejadian konkret yang harus segera direspon oleh seorang Presiden, dengan tetap membedakannya dengan prinsip Negara dalam keadaan bahaya maupun kegentingan memaksa di mana presiden dapat mengeluarkan Perppu tanpa perlu bertolak belakang dengan RUU GAAR.

\section{SARAN}

Mengingat dari kasus Baiq Nuril dapat dijadikan pelajaran untuk komunitas pengguna digital, berhati-hatilah saat mendistribusikan dokumen elektronik menggunakan jejaring sosial, perangkat digital, atau sistem pesan instan seperti Whatsapp, karena pada era ini terdapat regulasi yakni UU No. 19 Tahun 2016 perihal ITE, daripada itu Dewan Perwakilan Rakyat perlu segera merevisi atau mengganti UU Darurat di no. 11 ditahun 1954 disertai mengevalusi UU ITE

Penelitian mengenai urgensi dapat dikembangkan lagi menjadi bagaimana politik hukum yang tepat oleh pemerintah dalam pembentukan regulasi RUU GAAR dan muatan materi yang perlu diatur dalam RUU GAAR. Kemudian mengingat urgensi penyusunan RUU GAAR sebaiknya Kementerian Hukum dan HAM melalui stake holder di bawahnya (Balitbangkumham, BPHN, Ditjen AHU dan Ditjen PP) mempersiapkan kebutuhan dokumen pendukung serta mendorong RUU GAAR masuk ke dalam Prolegnas Prioritas pada Tahun 2022.

\section{UCAPAN TERIMA KASIH}

Kami menyadari bahwa penelitian ini belum sepenuhnya sempurna, sehingga tetap membutuhkan kritik dan saran dari berbagai pihak. Kami ucapkan terima kasih kepada narasumber antara lain, pakar hukum pidana dan tata negara, praktisi hukum, aparat penegak hukum (jaksa, hakim,) jajaran pejabat Kantor Wilayah Kementerian Hukum dan HAM, dan Pusat Penelitian dan Pengembangan Hukum (Balitbangkumham) yang telah membantu tim penelitian hingga tersusun karya tulis ilmiah ini.

\section{DAFTAR KEPUSTAKAAN}

Abdulkadir Muhammad. Hukum Dan Penelitian Hukum. Bandung: Citra Aditya Bakti, 2004.

Akhiar Salmi. "Focus Group Discussion (FGD) 'Urgensi Perubahan Undang-Undang Di Bidang Grasi, Amnesti, Abolisi Dan Rehabilitasi,"”2020.

Anonim. "Kasus Baiq Nuril: Solusi Hukum Grasi Atau Amnesti." Bbc Indonesia. Last modified 2018. Accessed January 13, 2021. https://www.bbc.com/indonesia/indonesia46278770.

Aristanti, Yuvina. "Sakit Berkepanjangan Sebagai Hak Untuk Mengajukan Grasi Berdasarkan Alasan Kemanusiaan Dan Keadilan.” Universitas Airlangga, 2019.

Asshiddiqie, Jimly. Pengantar Ilmu Hukum Tata Negara. Depok: Rajawali Pers, 2019.

Collins, Dio Ashar Wicaksana dan Josua Satria. "Analisis Dibalik Kontroversi Pemberian 
Amnesti Jokowi Kepada Baiq Nuril : Indonesia Butuh UU Amnesti Yang Baru." Dio Ashar Wicaksana Dan Josua Satria Collins. Last modified 2020. Accessed July 31, 2020. tehconversation.com.

Dkk, Mohammad Rezza Naufa. "Analisis Yuridis Putusan Mahkamah Konstitusi Nomor 107/PuuXiii/2015 Tentang Pengujian Undang-Undang Nomor 5 Tahun 2010 Tentang Perubahan Atas Undang-Undang Nomor 22 Tahun 2002 Tentang Grasi Terhadap Undang-Undang Dasar Negara Republik Indonesia Tahun 1945." Diponogoro Law, Fakultas Hukum Universitas Diponogoro Volume 6 N (2017): 3.

Falaakh, Moh. Fajrul. "AApakah Keppres Pemberian Grasi Objek TUN?" Hukum Online. Last modified 2020. Accessed January 21, 2021. https://www.hukumonline.com/klinik/detail/ ulasan/lt4fd2756d2c45d/grasi-presiden/.

Farid Wajdi, Andryan. "Konstitusi Terhadap, Sifat Putusan Impeachment Mahkamah Status Hukum Presiden Dan/Atau Wakil Presiden.” Jurnal Penelitian Hukum De Jure 20, no. 10 (2020): 301-314.

Irfani, Nurfaqih. "Asas Lex Superior, Lex Specialis, Dan Lex Posterior: Pemaknaan, Problematika, Dan Penggunaannya Dalam Penalaran Dan Argumentasi Hukum.” Jurnal Legislasi Volume 17 (2020).

KBBI. "Kamus Besar Bahasa Indonesia Online." Last modified 2020. Accessed July 30, 2020. http://bahasa.kemendiknas.go.id/kbbi/index. php.

Konstiyusi, Pertimbangan Hukum Mahkamah. Putusan Mahkamah Kontitusi Nomor 107/PUU-XIII/2015, (3.9.5) (2015).

MD, Mahfud. Dasar Dan Struktur Ketatanegaraan Indonesia. Edisi Revi. Jakarta: Rineka Cipta, 2001.

_. Membangun Politik Hukum Menegakkan Konstitusi. Jakarta: Rajawali Pers, 2010.

Nawawi, Hadari. Penelitian Terapan. Yogyakarta: Gadjah Mada University Press, 2005.

P, M. Marwan dan Jimmy. Kamus Hukum. Surabaya: Reality Publisher, 2009.

Ranggawidjaja, Rosjidi. Hubungan Tata Kerja Antara Majelis Permusyawaratan Rakyat, Dewan Perwakilan Rakyat Dan Presiden. Bandung: Gaya Media Pratama, 1990.

Rannie, H. Fahmi Yoesmar AR. dan Mahesa. "Hak Prerogatif Presiden Di Indonesia Pasca Amandemen UUD 1945." In Seminar
Nasional Hasil-Hasil Peneliti Ilmu Hukum Tahun 2015, 25. Palembang: Fakultas Hukum Universitas Sriwijaya, 2015.

Santoso, Agus. Hukum,Moral \& Keadilan Sebuah Kajian Filsafat Hukum. Ctk. Kedua. Jakarta: Kencana, 2014.

Siahaan, Maruarar. Hukum Acara Mahkamah Konstitusi. Jakarta: Sinar Grafika, 2012.

Situmorang, Mosgan. "Problematika Merehabilitasi Kedudukan Orang Yang Tersangkut Pidana Pada Keadaan Semula." Jurnal Penelitian Hukum De Jure 19, no. 2 (2019): 151.

Soekanto, Soerjono. Penelitian Hukum Normatif. Jakarta: PT Raja Grafindo Peresada, 2006.

Susanti, Bivitri. "Focus Group Discussion (FGD) 'Urgensi Perubahan Undang-Undang Di Bidang Grasi, Amnesti, Abolisi Dan Rehabilitasi,"”2020.

Susanto, Mei. "Kajian Putusan Mahkamah Konstitusi Nomor 22 / PUU-XIII / 2015 THE CONSTRUAL DEVELOPMENT An Analysis of Constitutional Court' s Decision Number 22 / PUU-XIII / 2015," no. 22 (2017): 237-258. 
HALAMAN KOSONG 